\title{
Effects of feeding dairy cows different legume-grass silages on milk phytoestrogen concentration
}

\author{
A. Höjer, ${ }^{1}$ S. Adler, †‡ S. Purup,§ J. Hansen-Møller, $\S^{2}$ K. Martinsson, ${ }^{*}$ H. Steinshamn, $\dagger$ and A.-M. Gustavsson* \\ *Swedish University of Agricultural Sciences, Department of Agricultural Research for Northern Sweden, SE-901 83 Umeå, Sweden \\ †Bioforsk-Norwegian Institute for Agricultural and Environmental Research, N-6630 Tingvoll, Norway \\ łNorwegian University of Life Sciences, Department of Animal and Aquacultural Sciences, PO Box 5003, N-1432 Ås, Norway \\ §Aarhus University, Department of Animal Science, Blichers Allé 20, PO Box 50, DK-8830 Tjele, Denmark
}

\begin{abstract}
Phytoestrogens are hormone-like substances in plants that can substantially influence human health (positively or negatively), and when fed to dairy cows are partly transferred to their milk. The aim of this study was to investigate the effects of varying the botanical composition and regrowth interval of legume-grass silage on phytoestrogen intake and milk phytoestrogen concentrations. In one experiment, 15 Swedish Red dairy cows were fed 2- or 3-cut red clover-grass silage, or 2-cut birdsfoot trefoil-grass silage. In a second experiment, 16 Norwegian Red dairy cows were fed short-term ley silage with red clover or long-term ley silage with white clover, and the effects of supplementation with $\alpha$-tocopherol were also tested. High concentrations of formononetin and biochanin A were found in all silage mixtures with red clover. The milk concentration of equol was highest for cows on the 2-cut red clover-grass silage diet $(1,494 \mu \mathrm{g} / \mathrm{kg}$ of milk). Because of the metabolism of biochanin A, genistein, and prunetin, their concentrations in milk and the apparent recovery were low. Coumestrol was detected in only short-term and long-term ley silage mixtures, and its milk concentration was low. Concentrations of secoisolariciresinol and matairesinol were higher in 2-cut birdsfoot trefoil-grass and long-term ley silage mixtures, those with legume species other than red clover, and the highest grass proportions. The 2-cut birdsfoot trefoil-grass silage diet also resulted in higher enterolactone concentration than the other diets $(226 \mu \mathrm{g} / \mathrm{kg}$ of milk). Lengthening the regrowth interval increased the intake of secoisolariciresinol and decreased the recovery of lignans. Feeding long-term ley silage resulted in higher milk lignan concentrations but lower milk isoflavone concentrations than feeding short-term ley silage. The apparent recovery of all phytoestrogens except prunetin was highest
\end{abstract}

Received December 5, 2011.

Accepted April 7, 2012.

${ }^{1}$ Corresponding author: annika.hojer@slu.se

${ }^{2}$ Present address: Cheminova A/S, DK-7673 Harboøre, Denmark. on the 2-cut birdsfoot trefoil-grass silage diet. No effect of $\alpha$-tocopherol supplementation was observed on milk concentrations of any of the measured phytoestrogens. Variations were observed in milk concentrations of phytoestrogens, especially of equol, among cows, which could not be explained by variations in diet composition or phytoestrogen intake. The results show that milk phytoestrogen concentration is strongly influenced by silage botanical composition, but questions regarding phytoestrogen metabolism remain to be answered. Key words: Trifolium species, Lotus corniculatus, estrogen receptor, ruminant

\section{INTRODUCTION}

Phytoestrogens, which are substances similar to $17 \beta$-estradiol that are present in diverse plant species, may interfere with estrogen receptors and inhibit or induce estrogenic responses in the animals or humans that consume them. Estrogenic compounds were originally found in plant materials in 1928. Since then, interest in phytoestrogens has strengthened because they have many proposed human health benefits. Notably, they may be protective against cancers (especially hormone-induced cancers, such as prostate and breast), reduce the risks of cardiovascular disease in women at menopause, or prevent osteoporosis. However, they may also have negative health effects; for example, they may interfere with sex hormone metabolism (Ososki and Kennelly, 2003).

Phytoestrogens are divided into groups based on their chemical structure. The main groups present in ruminant feeds are isoflavones, lignans, and coumestans (Mazur and Adlercreutz, 1998). Red clover (Trifolium pratensis L.) is known to have high isoflavone contents, and various factors (e.g., cultivar and harvest time) reportedly affect their concentrations (Saviranta et al., 2008). Zgórka (2009) reported that white clover (Trifolium repens L.) also has low isoflavone concentrations, and Mustonen et al. (2009) detected no isoflavones in timothy (Phleum pratense L.) or meadow fescue (Festuca pratensis Huds.). Levels of lignans have 
been measured in cereals, legumes, other vegetables, several oilseeds (e.g., linseed, Linum usitatissimum L.), and clover-grass silages (Steinshamn et al., 2008; Petit et al., 2009; Peterson et al., 2010). However, relatively little has been reported about effects of feed-relevant factors on their concentrations. Levels of coumestrol, a coumestan typically present in alfalfa (Medicago sativa L.), appear to be dependent on both cultivar and maturity and to decline during ensiling (Moravcová et al., 2004; Seguin et al., 2004). Phytoestrogens are also found in many products of animal origin (Kuhnle et al., 2008).

When feeding phytoestrogen-rich feed to dairy cows, the ingested phytoestrogens can be broken down into compounds with no estrogenic activity or pass through the rumen and intestines and be secreted through feces and urine. However, they may also be transferred to the milk (Tucker et al., 2010). One factor that reportedly affects milk phytoestrogen concentration is the botanical composition of the silage (Steinshamn et al., 2008; Mustonen et al., 2009). Notably, Andersen et al. (2009b) found that feeding grass-clover silage resulted in higher milk isoflavone and lower coumestrol concentrations than feeding alfalfa or corn (Zea mays L.) silage, whereas Steinshamn et al. (2008) found that feeding red clover-grass silage resulted in a higher isoflavone intake and lower lignan intake than feeding white clover-grass silages. Consequently, red clover diets resulted in higher isoflavone and lower lignan milk concentrations than did white clover diets. However, to our knowledge, no investigations have been published on the effects of birdsfoot trefoil (Lotus corniculatus L.) on phytoestrogen concentrations in milk.

In the rumen and the intestines, the isoflavones biochanin A and genistein are degraded by the microflora into $p$-ethylphenol, a substance with no estrogenic activity, whereas formononetin is metabolized into daidzein and subsequently into the isoflavan equol (Batterham et al., 1965; Lundh et al., 1990). Equol has high estrogenic activity and is reported to have health-promoting activities (e.g., Ingram et al., 1997; Lund et al., 2011; Tousen et al., 2011). Heinonen et al. (2001) reported that the lignans secoisolariciresinol and matairesinol are metabolized into the mammalian lignans enterodiol and enterolactone.

Our hypothesis was that feeding birdsfoot trefoil-grass silage would result in lower phytoestrogen (especially isoflavone) concentrations in the milk than would feeding red clover-grass silage. We also hypothesized that silage from red clover-grass leys with a shorter regrowth interval would increase milk phytoestrogen concentrations because of higher phytoestrogen concentrations in the silage. To our knowledge, no published comparisons are available on the effects of silage produced from long-term and short-term leys on milk phytoestrogen concentrations. Silage from short-term leys is thought to increase milk isoflavone concentration because of red clover in the mixture, but lignan concentration is probably higher in milk from cows on long-term ley silage because of herbs in the silage mixture.

\section{MATERIALS AND METHODS}

Two feeding experiments were carried out with dairy cows fed organically produced feed. One (designated experiment 1) was conducted at Röbäcksdalen Research Centre, Swedish University of Agricultural Sciences, Umeå, Sweden $\left(63^{\circ} 45^{\prime} \mathrm{N}, 20^{\circ} 17^{\prime} \mathrm{E} ; 5 \mathrm{~m}\right.$ above sea level), and the other (experiment 2) was conducted at the Animal Production Experimental Centre, As, Norway $\left(59^{\circ} 40^{\prime} \mathrm{N}, 10^{\circ} 46^{\prime} \mathrm{E} ; 100 \mathrm{~m}\right.$ above sea level). Use of animals in these experiments was approved by the Swedish Ethical Committee on Animal Experiments and according to regulations set by the Norwegian Animal Research Authority, respectively.

\section{Experimental Design}

In experiment 1 , a changeover Latin square design based on design number 2 by Patterson and Lucas (1962) was applied. The design included 3 periods, each 3 wk long, and 3 dietary treatments. Samplings were done at the end of each period, and then all cows were switched to a new diet. As a consequence, all cows received all diets. Treatments included preparing and feeding dairy cows (described below) silage from 2- or 3-cut red clover-grass systems (designated R2 and R3, respectively), or a 2-cut birdsfoot trefoil-grass system (B2). The spring growth in all cases was taken at the same date, when approximately $30 \%$ of the timothy plants were in stage 45 (the tip of the inflorescence in the flag leaf sheath; Gustavsson, 2011). The first and second cuts of the summer regrowth of the 3-cut system were taken 5 and $10 \mathrm{wk}$ after the spring growth, respectively, and the first cut of the summer regrowth in the 2-cut system was taken 7.5 wk after the spring growth. The silages were created from mixtures of these cuts (Table 1), with low proportions of spring growth material to meet the objective of comparing effects of summer regrowth duration. The proportion of summer regrowth cuts was representing approximate herbage yield.

In experiment 2, a changeover incomplete Latin square design was applied, again with three 3 -wk periods and 4 dietary treatments, with sampling in the last week of each period. The treatments included preparing and feeding dairy cows (described below) short-term ley silage (S3) and long-term ley silage (L3). As a 
Table 1. Dry matter concentrations $(\mathrm{g} / \mathrm{kg})$ and proportions $(\mathrm{g} / \mathrm{kg}$ of $\mathrm{DM})$ of the silages used in mixtures in experiment 1: 2-cut birdsfoot trefoilgrass silage (B2), 2-cut red clover-grass silage (R2), and 3-cut red clover-grass silage (R3)

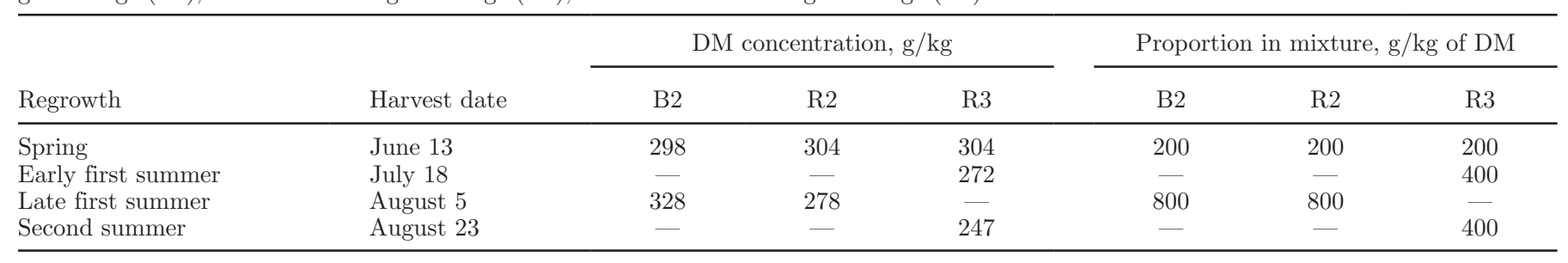

part of another study in this experiment, the effects of $\alpha$-tocopherol supplementation $(R R R$ - $\alpha$-tocopheryl acetate, $1,600 \mathrm{mg} / \mathrm{d}$; TPI, Madera, CA) were also studied (A. Höjer S. Adler, K. Martinsson, S. K. Jensen (Department of Animal Science, Aarhus University, Tjele, Denmark), H. Steinshamn, E. Thuen (Department of Animal and Aquacultural Sciences, Norwegian University of Life Sciences, Ås, Norway), and A.-M. Gustavsson, unpublished data). For this purpose, the diets of one-half of the cows on each silage treatment were supplemented with $\alpha$-tocopherol and one-half of the cows received no vitamin supplementation. After harvesting the leys (3 cuts), silages were prepared as mixtures of the cuts, in proportions reflecting the DM concentration of the bales (Table 2). The spring growth was taken at the booting stage of timothy, and the first and second summer regrowths were taken 7 and 15 wk thereafter.

\section{Silage Production}

In experiment 1, grass-legume systems were established in 2007 by sowing timothy cultivar (cv.) Grindstad, meadow fescue cv. Kasper and red clover cv. Betty (tetraploid Bjursele) seeds at 7.5, 10, and $8 \mathrm{~kg} / \mathrm{ha}$, respectively, in 1 field, and timothy cv. Grindstad and birdsfoot trefoil cv. Oberhaunstaedter seeds at 15 and $10 \mathrm{~kg} / \mathrm{ha}$, respectively, in another, with barley as a cover crop. At establishment, the fields were fertilized with cattle slurry (30 Mg/ha). The timothy-meadow fescuered clover field was divided into 6 strips, and each strip was randomly assigned for harvesting as either a 3-cut system or a 2-cut system. The birdsfoot trefoil-timothy field was harvested as a 2-cut system. At harvest, the crops were cut with a disc mower conditioner (model Ta 339; Kverneland Group, Kverneland, Norway), wilted, and precision chopped (JF-Fabrikken, Sønderborg, Denmark; theoretical chop length 16 to $32 \mathrm{~mm}$ ). Herbage from the spring growth, early summer regrowth, late summer regrowth, and second summer regrowth was wilted for $12,2,1$, and $12 \mathrm{~h}$, respectively, with the aim of obtaining a DM concentration of approximately $300 \mathrm{~g} / \mathrm{kg}$. The harvested herbages were preserved with an acid silage additive [ProMyr XR 630 (formic acid, 600 to $660 \mathrm{~g} / \mathrm{kg}$, and propionic acid, 250 to $300 \mathrm{~g} / \mathrm{kg}$ ); Perstorp AB, Perstorp, Sweden] at rates of 4, 5, 5, and $6 \mathrm{dm}^{3} / \mathrm{Mg}$ for the first growth, early summer regrowth, late summer regrowth, and second summer regrowth, respectively, based on the proportion of legumes and DM concentration. The silages were stored in 6 bunker silos. Their initial DM concentrations and botanical composition are shown in Tables 1 and 3, respectively.

In experiment 2, a long-term ley was established in 2003 by sowing seeds of timothy cv. Grindstad $(8 \mathrm{~kg} /$ ha), meadow fescue cv. Fure $(8 \mathrm{~kg} / \mathrm{ha})$, perennial ryegrass (Lolium perenne L.) cv. Napoleon (4 kg/ha), and white clover cv. Milkanova and Sonja $(2.5+2.5 \mathrm{~kg} /$ ha) and fertilizing with $25 \mathrm{Mg} / \mathrm{ha}$ of cattle slurry. In addition, a short-term ley was established in 2007 by sowing seeds of timothy cv. Grindstad and the diploid red clover cv. Bjursele at 27 and $1 \mathrm{~kg} /$ ha, respectively, fertilizing with $33 \mathrm{Mg} /$ ha of cattle slurry, and growing with barley as the cover crop. The 2 swards were harvested 3 times during 2008, and the yield was round-baled (Orkel GP 1260; Orkel, Fannrem, Norway) after 12 to $24 \mathrm{~h}$ of wilting and inoculated with an additive [GrasAAT N-Lacto (formic acid, 560 to $670 \mathrm{~g} /$ $\mathrm{kg}$, sodium formate, 140 to $200 \mathrm{~g} / \mathrm{kg}$, lactose, 10 to

Table 2. Dry matter concentrations $(\mathrm{g} / \mathrm{kg})$ and proportions $(\mathrm{g} / \mathrm{kg}$ of $\mathrm{DM})$ of the silages used in mixtures in experiment 2: short-term grassland silage (S3) and long-term grassland silage (L3)

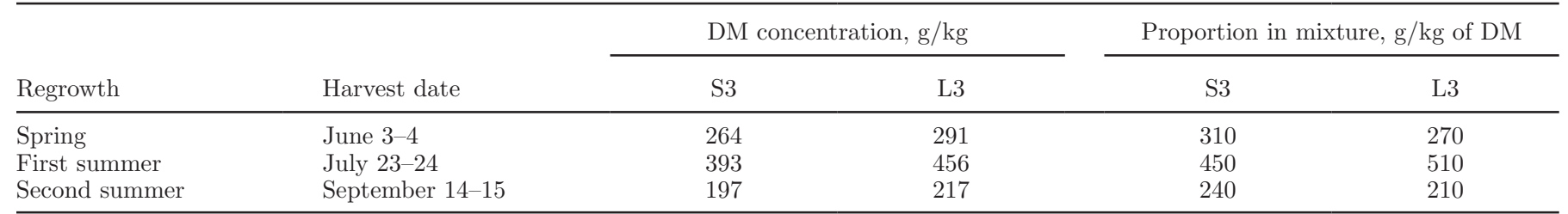


Table 3. Botanical composition $(\mathrm{g} / \mathrm{kg}$ of $\mathrm{DM})$ in forage mixtures determined from field sampling in experiment 1 used to prepare 2-cut birdsfoot trefoil-grass silage (B2), 2-cut red clover-grass silage (R2), and 3-cut red clover-grass silage (R3)

\begin{tabular}{lrrr}
\hline Forage & B2 & R2 & R3 \\
\hline Timothy (Phleum pratense L.) & 660 & 260 & 270 \\
Meadow fescue (Festuca pratensis Huds.) & 0 & 230 & 260 \\
Red clover (Trifolium pratensis L.) & 0 & 410 & 380 \\
Birdsfoot trefoil (Lotus corniculatus L.) & 160 & 0 & 0 \\
Other species $^{1}$ & 140 & 70 & 70 \\
Dead material & 40 & 30 & 20 \\
\hline
\end{tabular}

${ }^{1}$ Mainly Elytrigia repens L. and Alopecurus geniculatus L.

$20 \mathrm{~g} / \mathrm{kg}$, water, 110 to $260 \mathrm{~g} / \mathrm{kg}$ ); Addcon Nordic AS, Porsgrunn, Norway] at a rate of 4.0 to $4.6 \mathrm{dm}^{3} / \mathrm{Mg}$. Dry matter concentrations, harvest dates, proportions of cuts in mixtures, and botanical composition of the resulting silages are shown in Tables 2 and 4 .

\section{Animals and Diets}

In experiment 1, 15 multiparous Swedish Red dairy cows $[($ mean $\pm \mathrm{SD}) \mathrm{BW}, 658 \pm 58.9 \mathrm{~kg}$; initial DIM, $130 \pm 31.8$; initial milk yield, $30.2 \pm 4.2 \mathrm{~kg}$ of $\mathrm{ECM} / \mathrm{d}$ (ECM calculated according to the method of Sjaunja et al., 1991)] were blocked according to milk yield and DIM, and randomly within block were allocated to the 3 dietary treatments. All cows were fed silage ad libitum through roughage intake-control feeders (Insentec B.V., Marknesse, the Netherlands) and $5.4 \mathrm{~kg}$ of DM concentrate/d. The composition of the concentrate was set to meet the protein requirements for cows consuming the silage with the lowest $\mathrm{CP}$ concentration (B2; Tables 5, 6, and 7). Concentrate allotment was limited to a maximum of $2 \mathrm{~kg} / 8 \mathrm{~h}$ and was fed separately in feeders. The cows were kept in a loose-housing barn and were milked twice a day at 0600 and $1600 \mathrm{~h}$.

In experiment 2, 16 multiparous Norwegian Red dairy cows [(mean $\pm \mathrm{SD}) \mathrm{BW}, 617 \pm 66.5 \mathrm{~kg}$; initial DIM, $129 \pm 14.2$; milk yield, $34.6 \pm 2.5 \mathrm{~kg}$ of $\mathrm{ECM} / \mathrm{d}]$

Table 4. Botanical composition $(\mathrm{g} / \mathrm{kg}$ of $\mathrm{DM})$ in forage mixtures determined from field sampling in experiment 2 used to prepare shortterm grassland silage (S3) and long-term grassland silage (L3)

\begin{tabular}{lrr}
\hline Forage & S3 & L3 \\
\hline Timothy (Phleum pratense L.) & 510 & 440 \\
Meadow fescue (Festuca pratensis Huds.) & 0 & 150 \\
Perennial ryegrass (Lolium perenne L.) & 50 & 90 \\
Red clover (Trifolium pratensis L.) & 310 & 0 \\
White clover (Trifolium repens L.) & 40 & 210 \\
Couch grass (Elytrigia repens L.) & 40 & 30 \\
Dandelion (Taraxacum spp.) & 0 & 20 \\
Other species ${ }^{1}$ & 10 & 0 \\
Dead material & 40 & 60 \\
\hline
\end{tabular}

${ }^{1}$ Mainly Rumex longifolius DC.
Table 5. Ingredient composition of the concentrate supplements used in experiments 1 and 2

\begin{tabular}{lcc}
\hline Ingredient, g/kg feed & Experiment 1 & Experiment 2 \\
\hline Barley (Hordeum vulgare L.) & 350 & 920 \\
Rapeseed cake (Brassica napus L.) & 420 & - \\
Pea (Pisum sativum L.) & 200 & - \\
Sugar beet molasses & 10 & 50 \\
Mineral and vitamin premix & 20 & 30 \\
\hline
\end{tabular}

were blocked according to sire, DIM, and milk yield and allocated randomly within block to 3 of the 4 dietary treatments. All cows were offered silage ad libitum through roughage intake-control feeders (Biocontrol AS, Rakkestad, Norway). Concentrate was given separately at a level of $5.4 \mathrm{~kg}$ of DM/d (Felleskjøpet, Norway; Tables 5 and 6). Concentrate allotment was limited to a maximum of $1.5 \mathrm{~kg} / 6 \mathrm{~h}$. The cows were kept in a loose housing barn and were milked twice a day at 0600 and $1600 \mathrm{~h}$.

\section{Samplings and Sample Preparation}

Fresh Herbage, Silage, and Concentrate. In experiment 1, fresh herbage was sampled at the time of each harvest by cutting 2 circular $0.5-\mathrm{m}^{2}$ plots at stubble height (3 to $5 \mathrm{~cm}$ above ground) at 3 spots distributed diagonally across each field, 6 plots in total per field. The plant material was hand-separated

Table 6. Chemical composition, feed values of concentrate supplements ( $\mathrm{g} / \mathrm{kg}$ of DM unless otherwise stated), and phytoestrogen concentration $(\mathrm{mg} / \mathrm{kg}$ of $\mathrm{DM}$; mean $\pm \mathrm{SD})$

\begin{tabular}{lcc}
\hline Item & Experiment 1 & Experiment 2 \\
\hline $\mathrm{n}$ & 6 & 6 \\
$\mathrm{DM}, \mathrm{g} / \mathrm{kg}$ & $897 \pm 1.1$ & $907 \pm 2.7$ \\
$\mathrm{Ash}$ & $65 \pm 1.7$ & $43 \pm 2.3$ \\
$\mathrm{CP}$ & $233 \pm 1.0$ & $122 \pm 4.5$ \\
$\mathrm{Soluble} \mathrm{CP,} \mathrm{g/kg} \mathrm{of} \mathrm{CP}$ & $535 \pm 19.1$ & $245 \pm 50.9$ \\
$\mathrm{ADF}$ & $117 \pm 6.6$ & $65 \pm 6.3$ \\
$\mathrm{NDF}$ & $186 \pm 3.0$ & $178 \pm 10.9$ \\
Starch & $287 \pm 8.7$ & $534 \pm 14.8$ \\
$\mathrm{NFC}$ & $459 \pm 3.5$ & $650 \pm 9.5$ \\
$\mathrm{Crude}$ fat & $73 \pm 2.2$ & $26 \pm 2.0$ \\
IVTD 48 $\mathrm{h}^{1}$ & $903 \pm 15.0$ & $915 \pm 26.6$ \\
NDFD ${ }^{2} \mathrm{~g} / \mathrm{kg}$ of NDF & $480 \pm 84.9$ & $520 \pm 167.0$ \\
NE $\mathrm{L}, \mathrm{MJ} / \mathrm{kg}$ of DM & $8.3 \pm 0.04$ & $7.8 \pm 0.07$ \\
Phytoestrogen, mg/kg of DM & & \\
Formononetin & $0.7 \pm 0.07$ & $1.1 \pm 0.11$ \\
Daidzein & $1.5 \pm 0.21$ & $1.9 \pm 2.55$ \\
Biochanin A & $1.0 \pm 0.33$ & $1.0 \pm 0.55$ \\
Genistein & $2.5 \pm 0.51$ & $3.0 \pm 4.08$ \\
Prunetin & $\mathrm{ND}$ & $\mathrm{ND}$ \\
Coumestrol & $\mathrm{ND}$ & $\mathrm{ND}$ \\
Secoisolariciresinol & $\mathrm{ND}$ & $\mathrm{ND}$ \\
Matairesinol & $\mathrm{ND}$ & $\mathrm{ND}$ \\
\hline
\end{tabular}

${ }^{1}$ IVTD $=$ in vitro true digestibility, $48 \mathrm{~h}$.

${ }^{2} \mathrm{NDFD}=\mathrm{NDF}$ digestibility.

${ }^{3} \mathrm{ND}=$ under the detection limits. 
Table 7. Chemical composition, feed values, fermentation products ( $\mathrm{g} / \mathrm{kg}$ of DM, unless otherwise stated), and phytoestrogen concentrations $(\mathrm{mg} / \mathrm{kg}$ of DM) of the silages used in experiment 1 [2-cut birdsfoot grass-silage (B2), 2-cut red clover-grass silage (R2), and 3-cut red clover-grass silage (R3); mean $\pm \mathrm{SD}$ ] and in experiment 2 [short-term grassland silage (S3) and long-term grassland silage (L3); mean \pm SD]

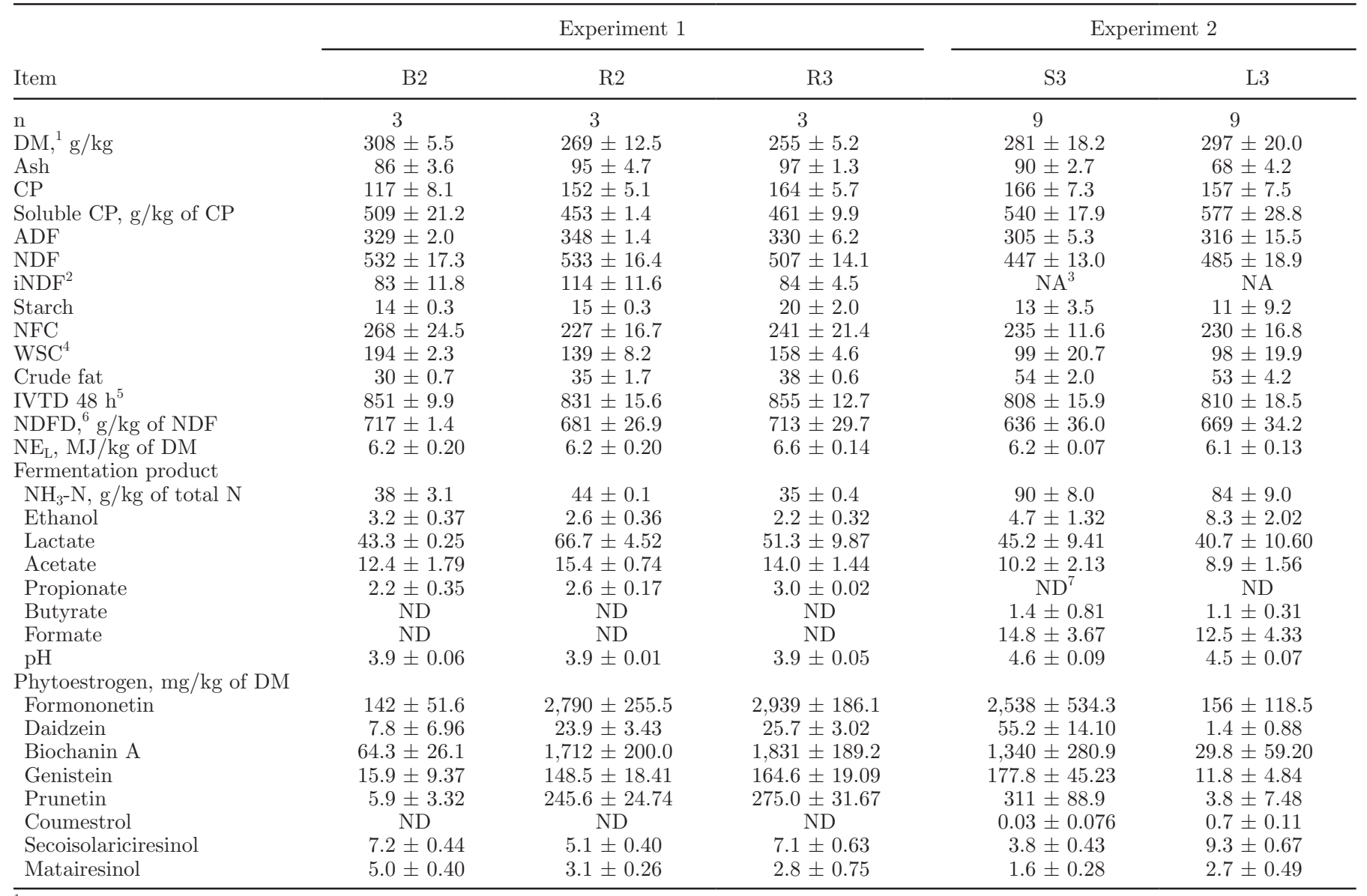

${ }^{1}$ Corrected for fermentation product losses.

${ }^{2} \mathrm{iNDF}=$ indigestible NDF.

${ }^{3} \mathrm{NA}=$ not analyzed.

${ }^{4} \mathrm{WSC}=$ water-soluble carbohydrates.

${ }^{5} \mathrm{IVTD}=$ in vitro true digestibility, $48 \mathrm{~h}$.

${ }^{6} \mathrm{NDFD}=\mathrm{NDF}$ digestibility.

${ }^{7} \mathrm{ND}=$ under the detection limit.

by species and dried at $60^{\circ} \mathrm{C}$ for $48 \mathrm{~h}$ in a forced-air oven. Silage samples were collected daily during the last week of each period, pooled, split into 3 subsamples, and stored frozen $\left(-20^{\circ} \mathrm{C}\right)$ until all samples had been collected. One set of silage subsamples, for feed value analysis, was dried $\left(60^{\circ} \mathrm{C}\right.$ for $48 \mathrm{~h}$ in a forced-air oven) and milled in a cutting mill with a $1.0-\mathrm{mm}$ screen (SM 2000, Retsch GmbH, Haan, Germany). A second set, for phytoestrogen analysis, was freeze-dried, milled, and then stored frozen $\left(-20^{\circ} \mathrm{C}\right)$. The third set, for fermentation product analysis, was kept frozen until analysis. Two samples of the concentrate were collected in each sampling week and stored frozen $\left(-20^{\circ} \mathrm{C}\right)$ until analysis.
In experiment 2 , vegetation in 6 rectangular $0.5-\mathrm{m}^{2}$ plots distributed randomly across the fields was handclipped at a stubble height of $5 \mathrm{~cm}$ shortly before each cut and weighed. Approximately $0.5 \mathrm{~kg}$ of the herbage mass was hand-separated by species and dead material, and then oven-dried at $105^{\circ} \mathrm{C}$ for $24 \mathrm{~h}$. Samples of the silages were collected on $3 \mathrm{~d}$ in each sampling week and frozen $\left(-20^{\circ} \mathrm{C}\right)$ until all samples were collected. The samples were then chopped and split into 2 equal subsamples, one of which was kept frozen until analysis of fermentation products and the other of which was freeze-dried (Christ LCM-2 $\beta$ 1-16 and Christ LOC-1 m a 1-4; Martin Christ, Osterode am Harz, Germany, and Hetosicc, Birkerød, Denmark, respectively), ground 
in a cutting mill $(<1.0 \mathrm{~mm}$, Retsch SM 100; Retsch $\mathrm{GmbH}$, Haan, Germany) and stored frozen $\left(-20^{\circ} \mathrm{C}\right)$ until feed value and phytoestrogen concentration analysis. Samples of the concentrate were collected in each sampling week (pooled samples from d 1 to 3), freeze-dried, ground through a 1.0-mm screen, and stored frozen $\left(-20^{\circ} \mathrm{C}\right)$ until feed value and phytoestrogen concentration analysis.

Milk Sampling. Milk samples for phytoestrogen analysis were taken at 4 consecutive milkings from each cow at the end of each period (evening d 19, morning and evening d 20, morning d 21 after the diet switch in experiment 1 ; evening d 15, morning and evening $\mathrm{d}$ 16 , morning $\mathrm{d} 17$ after the diet switch in experiment 2). The samples were stored at $4^{\circ} \mathrm{C}$ until all samples were collected. They were then reheated to $37^{\circ} \mathrm{C}$ in a water bath, gently blended in aliquot proportions, and stored frozen $\left(-20^{\circ} \mathrm{C}\right)$ until analyses were performed.

In experiment 1 , samples for milk fat and protein concentration determinations were taken at 2 consecutive milkings (evening d 19 and morning d 20 after the diet switch) in each period and at the same time as samples for phytoestrogen analysis in experiment 2 . The samples were preserved with 2-bromo-2-nitropropane-1,3-diol (Bronopol, D\&F Inc., Dublin, CA).

\section{Analytical Methods}

Chemical Analysis of Forages, Concentrates, and Milk. Forage and concentrate samples were analyzed at the Dairy One forage laboratory, Ithaca, New York. The analyses included determinations of ash (method 942.05; AOAC, 1990), CP (using a Leco FP-528 combustion analyzer; Leco Corporation, St. Joseph, MI), soluble CP (Cornell Sodium BorateSodium Phosphate Buffer Procedure), ADF (Ankom A200 Filter Bag Technique; Ankom Technology, Macedon, NY), NDF (Ankom A200 Filter Bag Technique with Amylase), starch (YSI 2700 Select Biochemistry Analyzer; YSI Inc. Life Sciences, Yellow Springs, OH), water-soluble carbohydrates (West Virginia University Procedure; Hall et al., 1999), crude fat (AOAC method 2003.05, ether extraction method), and in vitro true digestibility and NDF digestibility (Ankom Daisy II Filter Bag Technique, involving incubation for $48 \mathrm{~h}$ in a Van Soest buffer/rumen fluid mixture). The $\mathrm{NE}_{\mathrm{L}}$ was calculated according to NRC (2001) guidelines. Indigestible NDF concentration was determined only in experiment 1 by in situ rumen incubation of feed samples for $288 \mathrm{~h}$ (Huhtanen et al., 1994) in 3 rumencannulated Swedish Red dairy cows. Fat and protein concentrations in milk samples were analyzed using a Fourier transform infrared spectroscopy (FTIR) milk analyzer (a MilkoScan 4000 FTIR instrument in experi- ment 1, and a MilkoScan 6000 FTIR instrument in experiment 2, both from FOSS Analytical A/S, Hillerød, Denmark).

Analysis of Fermentation Products. In experiment 1 , ethanol and formic, acetic, propionic, butyric, and lactic acids were analyzed by HPLC, using a system consisting of an Alliance 2795 Separations Module, Temperature-Control Module II (range 40 to $70^{\circ} \mathrm{C}$ ), a 2414 Refractive Index Detector (all from Waters Corporation, Milford, MA), and a ReproGel H 9- $\mu \mathrm{m} 300$ $\times 8 \mathrm{~mm}$ separation column (Dr. A. Maisch GmbH, Ammerbuch, Germany). The mobile phase was 0.005 $M$ sulfuric acid, and the flow rate was $0.8 \mathrm{~mL} / \mathrm{min}$. Ammonia- $\mathrm{N}$ was analyzed by flow injection analysis (Application Note ASN 50-01/92; FOSS Tecator, Hillerød, Denmark) and Kjeldahl-N was analyzed with a 2020 Digestor and a 2400 Kjeltec Analyzer Unit (FOSS Analytical A/S) and values were corrected for drying losses of N according to NorFor (Volden, 2011). The $\mathrm{pH}$ of fresh silage juice was determined using a Metrohm $654 \mathrm{pH}$ meter (Metrohm, Herisau, Switzerland). Dry matter concentrations of the silages were determined by weighing samples before and after drying at $103^{\circ} \mathrm{C}$ for $16 \mathrm{~h}$.

In experiment 2, formic, acetic, propionic, butyric, and lactic acid contents of the silages were determined by HPLC, using a VA 300/7.8 Nucleogel Ion 300 OA column (Machery-Nagel GmbH \& Co. KG, Düren, Germany) and either an UV spectrophotometric detector (for lactic acid) or a refractive index detector (for the other acids). Ethanol and ammonium-N analysis contents were determined using a PC-titrate system (MAN-TECH Guelph, ON, Canada) and an Orion 901 ion analyzer (Thermo Scientific, Beverly, MA), and $\mathrm{pH}$ was determined with a Thermo Orion $420 \mathrm{~A}+\mathrm{pH}$ meter equipped with an Orion 9107BN electrode (Thermo Scientific). Dry matter concentrations of the silages were determined by weighing samples before and after drying at $103^{\circ} \mathrm{C}$ for $24 \mathrm{~h}$.

Phytoestrogen Analysis. Phytoestrogen concentrations in feed and milk were analyzed according to methods described in Steinshamn et al. (2008). Briefly, feed samples were prepared by extraction with a mixture of ethanol and acetate buffer, followed by incubation with Cellulase Onozuka R-10 (Merck, Darmstadt, Germany) overnight at room temperature and centrifugation. Milk samples were defatted and deproteinized by mixing with acetate buffer, heptane, and acetone, followed by incubation with a mixture of $\beta$-glucuronidase and Helix pomatia sulfatase type H2 (all from Sigma-Aldrich, St. Lois, MO) and centrifugation. Phytoestrogens in the resulting extracts were separated and analyzed using an HP 1100 HPLC system equipped with a Zorbax XDB column (both from Agilent, Wilmington, DE), coupled 
to a Quattro LC MS-MS instrument (Micromass, Manchester, UK). Phytoestrogens analyzed were the isoflavones formononetin, daidzein, biochanin A, genistein, and prunetin, the isoflavan equol, the coumestan coumestrol, and the lignans secoisolariciresinol, matairesinol, enterodiol, and enterolactone.

\section{Statistical Analysis}

Effects of the treatments on the measured variables were analyzed using the MIXED model procedure implemented in SAS software (SAS Institute, 2008). Milk yield and feed intake were registered daily throughout the experiments, but only observations of these variables from the last $2 \mathrm{wk}$ in each period of experiment 1 , and observations from the last week in each period of experiment 2 were used for statistical analysis. The same statistical model was used to explore relationships in the data from both experiments:

$$
\mathrm{Y}_{\mathrm{ijkl}}=\mu+\mathrm{F}_{\mathrm{i}}+\mathrm{P}_{\mathrm{j}}+\mathrm{b}_{\mathrm{k}}+\mathrm{c}_{\mathrm{l}}+\mathrm{e}_{\mathrm{ijkl} \mathrm{l}},
$$

where $\mathrm{Y}$ is the response variable, $\mu$ is the LSM, F is the fixed effect of diet (experiment 1, $\mathrm{i}=\mathrm{R} 2, \mathrm{R} 3, \mathrm{~B} 2$; experiment $2, \mathrm{i}=\mathrm{S} 3$ without $\alpha$-tocopherol supplementation, S3 with $\alpha$-tocopherol supplementation, L3 without $\alpha$-tocopherol supplementation, L3 with $\alpha$-tocopherol supplementation), $P$ is the fixed effect of period $(j=1$ to 3 ), $\mathrm{b}$ is the random effect of block (experiment $1, \mathrm{k}=$ 1 to 5 ; experiment $2, \mathrm{k}=1$ to 4 ), c is the random effect of cow (experiment $1,1=1$ to 15 ; experiment $2,1=1$ to 16 ), and e is the random residual error. When phytoestrogen concentrations were below the detection limit, one-half the detection limit was used in the statistical analysis. Differences between LSM of response variables in experiment 1 were estimated with Tukey's test, and contrasts were calculated to assess the effects of silage type, $\alpha$-tocopherol supplementation, and the interaction of silage type $\times \alpha$-tocopherol supplementation in experiment 2. No significant effect of $\alpha$-tocopherol supplementation on any of the response variables was detected, and no significant interaction was observed between silage treatment and $\alpha$-tocopherol supplementation. Therefore, only the effects of the silage treatment are considered here, and the presented means are for all cows on the same silage diet. Treatment means were considered significantly different when $P<0.05$.

\section{RESULTS}

\section{Effects of Botanical Composition and Regrowth Interval (Experiment 1)}

The silage mixtures with red clover (R2 and R3) had lower DM concentrations (Table 1), higher legume proportions (Table 3), and higher $\mathrm{CP}$ concentrations (Table 7) than the mixture with birdsfoot trefoil (B2). The differences between R2 and R3 were relatively small. In addition, the in vitro true digestibility and NDF digestibility were higher and the indigestible NDF concentration was lower in B2 and R3 than in R2. The water-soluble carbohydrates were highest for B2 and lowest for R3, with R2 in between. The fermentation product analysis indicated that all 3 silages were well fermented, with low proportions of ammonium- $\mathrm{N}$ and $\mathrm{pH}$ around 4.

Silage and total DMI were higher for B2 than for R2 and R3, and CP intake was lower for B2 than for R2 and R3 (Table 8). No significant between-diet differences were observed in milk yield or in milk fat or milk protein concentrations (Table 9).

Formononetin, Daidzein, and Equol Contents. Substantially higher concentrations of formononetin and daidzein were observed in silage mixture R2 and R3 than in mixture B2 (Table 7). Intakes of formononetin and daidzein were substantially higher for cows on R2 and R3 than those on B2 (Table 8). In the milk, the formononetin and daidzein concentrations were twice and 3 times higher for cows on R2 and R3, respectively, than those on B2 (Table 9). However, the largest observed difference in milk phytoestrogen contents between the red clover and the birdsfoot trefoil diets was in equol concentration, which was approximately 10 times higher for cows on R2 and R3. Conversely, the apparent recovery (sum of formononetin, daidzein, and equol secreted into milk divided by the summed intake of formononetin and daidzein) was higher for cows on B2 than those on R2 and R3.

Biochanin $A$ and Genistein Contents. The silage mixtures with red clover had higher concentrations of biochanin A and genistein than did the mixture with birdsfoot trefoil, which gave higher intakes of these substances (Tables 7 and 8) and higher milk concentrations (Table 9). However, apparent recovery of biochanin A and genistein (sum of biochanin A and genistein secreted into milk divided by the summed intake of biochanin A and genistein) was higher for cows on B2 than for those on R2 and R3 (Table 9).

Prunetin Contents. The prunetin concentration was much higher in silage mixtures R2 and R3 than in B2, leading to approximately 35 times higher intake (Tables 7 and 8). A higher concentration of prunetin in milk was observed for cows on R2 and R3 than for those on B2 (Table 9), but the difference was numerically small. Apparent recovery (prunetin secreted into milk divided by intake of prunetin) was much higher for cows on B2 than for those on the other 2 diets (Table 9).

Coumestrol Contents. Coumestrol was not detected in any of the silage mixtures (Table 7). The 
Table 8. Effect of feeding cows the following silages on silage intake, total DMI, crude fat intake, CP intake, and phytoestrogen intake: 2-cut birdsfoot trefoil-grass silage (B2), 2-cut red clover-grass silage (R2), 3-cut red clover-grass silage (R3) in experiment 1; and short-term grassland (S3) or long-term grassland (L3) silage in experiment $2^{1}$

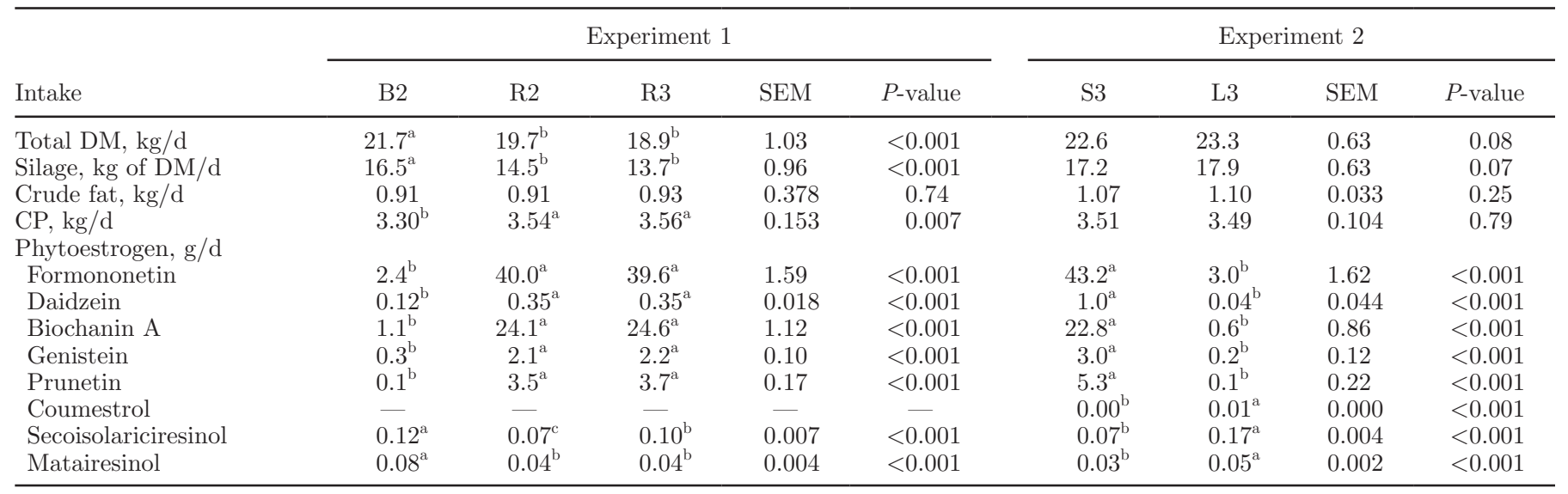

${ }^{\mathrm{a}-\mathrm{c}}$ Lowercase characters indicate significantly different means within the experiment $(P<0.05)$.

${ }^{1}$ Presented values are LSM with SEM.

concentration in the milk was low, and no between-diet differences in coumestrol were observed (Table 9).

Lignan Contents. The concentration of secoisolariciresinol was slightly higher in silage mixtures B2 and R3 than in R2 (Table 7). The concentration of matairesinol was higher in silage mixture B2 than in R2 and R3. Combined with the higher silage intake, intakes of secoisolariciresinol and matairesinol were higher for cows on B2 than for those on R2 and R3 (Table 8). The intake of secoisolariciresinol was higher for cows on R3 than for those on R2. No significant between-diet differences in milk concentrations of secoisolariciresinol or matairesinol were observed, but the concentrations of enterodiol and enterolactone differed (Table 9). The apparent recovery of lignans (sum of secoisolariciresinol, matairesinol, enterodiol, and enterolactone secreted into milk divided by the summed intake of secoisolariciresinol and matairesinol) was higher for cows on diet R3 than for those on diets R2 and B2.

\section{Effects of Ley Management (Experiment 2)}

A higher proportion of legumes was observed in silage mixture S3 than in L3 (Table 4). A higher concentration of ash, a lower concentration of NDF, and lower NDF digestibility were observed in silage mixture S3 than in L3 (Table 7). Silage DMI tended to be higher for cows on L3 (Table 8). The ECM yield and both milk fat and protein concentrations were also higher for cows on L3 (Table 9).

Formononetin, Daidzein, and Equol Contents. Much higher concentrations of formononetin and daidzein were observed in silage mixture S3 than in mixture L3 (Table 7), resulting in higher intakes of these substances on S3 (Table 8). Milk concentrations of formononetin and daidzein were higher for cows on S3 (Table 9) and the equol concentration was 8 times higher for cows on S3 than for those on L3. Apparent recovery was twice as high for cows on L3 as for those on S3.

Biochanin A and Genistein Contents. As seen for the other isoflavones, the concentrations of biochanin A and genistein were higher in the red clovercontaining silage mixture S3 (Table 7). Accordingly, intakes of genistein and biochanin A were higher (15and almost 40-fold, respectively) and their milk concentrations were higher for cows on S3 than for those on L3 (Tables 8 and 9). Apparent recovery was higher for cows on L3, but as in experiment 1, the recovery was low for cows on both diets.

Prunetin Contents. As in experiment 1, the prunetin concentration was higher in the silage mixture with red clover (Table 7), and its intake was more than 50 times higher for cows on S3 than for those on L3 (Table 8). In the milk, the concentration was higher for cows on S3, but less numerical difference was observed than for the intake (Table 9). The apparent recovery was higher for cows on L3 than for those on S3.

Coumestrol Contents. The concentration of coumestrol was higher in silage mixture L3, but for both silages, the concentration and intake were low (Tables 7 and 8). Its milk concentration was twice as high for cows on L3 as for those on S3 (Table 9). Apparent recovery of coumestrol (coumestrol secreted into milk divided by coumestrol intake) was higher for cows on S3, but because the intake was quite low, the reliability of the recovery measurements is questionable. 
Table 9. Effects of feeding cows the following silages on concentrations of phytoestrogens in milk: 2-cut birdsfoot trefoil-grass silage (B2), 2-cut red clover-grass silage (R2), 3-cut red clover-grass silage (R3) in experiment 1; and short-term grassland (S3) or long-term grassland (L3) silage in experiment 2

\begin{tabular}{|c|c|c|c|c|c|c|c|c|c|}
\hline \multirow[b]{2}{*}{ Item } & \multicolumn{5}{|c|}{ Experiment 1} & \multicolumn{4}{|c|}{ Experiment 2} \\
\hline & $\mathrm{B} 2$ & $\mathrm{R} 2$ & R3 & SEM & $P$-value & S3 & L3 & SEM & $P$-value \\
\hline Milk yield, $\mathrm{kg} / \mathrm{d}$ & 26.0 & 25.5 & 26.1 & 1.49 & 0.36 & 26.2 & 26.4 & 0.79 & 0.45 \\
\hline $\mathrm{ECM}, \mathrm{kg} / \mathrm{d}$ & 27.8 & 27.1 & 27.8 & 1.59 & 0.23 & $27.1^{\mathrm{b}}$ & $27.9^{\mathrm{a}}$ & 0.94 & 0.003 \\
\hline Fat, $\mathrm{g} / \mathrm{kg}$ of milk & 45.0 & 44.5 & 44.8 & 0.80 & 0.70 & $42.8^{\mathrm{b}}$ & $44.6^{\mathrm{a}}$ & 1.3 & $<0.001$ \\
\hline Protein, $\mathrm{g} / \mathrm{kg}$ of milk & 35.2 & 34.8 & 35.0 & 0.57 & 0.15 & $33.7^{\mathrm{b}}$ & $34.3^{\text {a }}$ & 0.8 & 0.01 \\
\hline \multicolumn{10}{|l|}{ Phytoestrogen, $\mu \mathrm{g} / \mathrm{kg}$ of milk } \\
\hline Formononetin & $5.9^{\mathrm{b}}$ & $12.6^{\mathrm{a}}$ & $13.1^{\mathrm{a}}$ & 0.75 & $<0.001$ & $9.9^{\mathrm{a}}$ & $4.8^{\mathrm{b}}$ & 1.06 & $<0.001$ \\
\hline Daidzein & $4.9^{\mathrm{b}}$ & $16.0^{\mathrm{a}}$ & $15.3^{\mathrm{a}}$ & 1.09 & $<0.001$ & $7.1^{\mathrm{a}}$ & $2.1^{\mathrm{b}}$ & 1.23 & $<0.001$ \\
\hline Equol & $145^{\mathrm{b}}$ & $1,494^{\mathrm{a}}$ & $1,297^{\mathrm{a}}$ & 134.0 & $<0.001$ & $716^{\mathrm{a}}$ & $84^{\mathrm{b}}$ & 101.9 & $<0.001$ \\
\hline Biochanin A & $1.2^{\mathrm{b}}$ & $3.9^{\mathrm{a}}$ & $4.5^{\mathrm{a}}$ & 0.31 & $<0.001$ & $3.0^{\mathrm{a}}$ & $0.5^{\mathrm{b}}$ & 0.45 & $<0.001$ \\
\hline Genistein & $6.1^{\mathrm{b}}$ & $9.9^{\mathrm{a}}$ & $9.3^{\mathrm{a}}$ & 0.52 & $<0.001$ & $3.9^{\mathrm{a}}$ & $2.3^{\mathrm{b}}$ & 0.31 & $<0.001$ \\
\hline Prunetin & $1.4^{\mathrm{b}}$ & $2.0^{\mathrm{a}}$ & $1.8^{\mathrm{a}}$ & 0.13 & $<0.001$ & $2.3^{\mathrm{a}}$ & $1.1^{\mathrm{b}}$ & 0.45 & 0.01 \\
\hline Coumestrol & 0.2 & 0.1 & 0.2 & 0.06 & 0.77 & $0.4^{\mathrm{b}}$ & $0.8^{\mathrm{a}}$ & 0.15 & 0.02 \\
\hline Secoisolariciresinol & 10.2 & 10.1 & 10.3 & 0.34 & 0.84 & 5.9 & 6.1 & 0.29 & 0.48 \\
\hline Matairesinol & 2.0 & 1.8 & 1.8 & 0.12 & 0.43 & 1.1 & 1.3 & 0.18 & 0.10 \\
\hline Enterodiol & $0.8^{\mathrm{a}}$ & $0.7^{\mathrm{b}}$ & $0.7^{\mathrm{b}}$ & 0.06 & 0.014 & $0.5^{\mathrm{b}}$ & $0.8^{\mathrm{a}}$ & 0.04 & $<0.001$ \\
\hline Enterolactone & $225.6^{\mathrm{a}}$ & $107.8^{\mathrm{b}}$ & $79.4^{\mathrm{b}}$ & 13.95 & $<0.001$ & $50.8^{\mathrm{b}}$ & $133.3^{\mathrm{a}}$ & 14.72 & $<0.001$ \\
\hline \multicolumn{10}{|c|}{ Apparent recovery, feed to milk, $\mathrm{mg} / \mathrm{g}$} \\
\hline Formononetin + daidzein $^{2}$ & $1.83^{\mathrm{a}}$ & $1.07^{\mathrm{b}}$ & $0.96^{\mathrm{b}}$ & 0.22 & 0.002 & $0.48^{\mathrm{b}}$ & $1.00^{\mathrm{a}}$ & 0.119 & $<0.001$ \\
\hline Biochanin $\mathrm{A}+$ genistein $^{3}$ & $0.15^{\mathrm{a}}$ & $0.01^{\mathrm{b}}$ & $0.01^{\mathrm{b}}$ & 0.007 & $<0.001$ & $0.01^{\mathrm{b}}$ & $0.14^{\mathrm{a}}$ & 0.012 & $<0.001$ \\
\hline Prunetin $^{4}$ & $0.47^{\mathrm{a}}$ & $0.02^{\mathrm{b}}$ & $0.01^{\mathrm{b}}$ & 0.04 & $<0.001$ & 0.01 & 0.79 & 0.243 & 0.003 \\
\hline Coumestrol $^{5}$ & - & - & - & - & - & 3.07 & 1.62 & 0.574 & 0.04 \\
\hline Lignans $^{6}$ & $33.5^{\mathrm{a}}$ & $28.9^{\mathrm{a}}$ & $18.5^{\mathrm{b}}$ & 3.21 & $<0.001$ & 16.1 & 17.4 & 1.99 & 0.31 \\
\hline
\end{tabular}

${ }_{\mathrm{a}, \mathrm{b}}^{\mathrm{b}}$ Lowercase characters indicate significantly different means within experiment $(P<0.05)$.

${ }^{1}$ Presented values are LSM with standard error of means.

${ }^{2}$ (Sum of equol, formononetin, and daidzein secreted in milk)/(sum of formononetin and daidzein intake).

${ }^{3}$ (Sum of biochanin A and genistein secreted in milk)/(sum of biochanin A and genistein intake).

${ }^{4}$ (Prunetin secreted in milk)/(prunetin intake).

5 (Coumestrol secreted in milk)/(coumestrol intake).

${ }^{6}$ (Sum of secoisolariciresinol, matairesinol, enterodiol, and enterolactone in milk)/(sum of secoisolariciresinol and matairesinol intake). 
Lignan Contents. The concentrations of secoisolariciresinol and matairesinol were higher in silage mixture L3 than in S3; consequently, their intakes were higher (Tables 7 and 8). In milk, higher concentrations of the mammalian lignans enterodiol and enterolactone were observed for cows on L3 than for those on S3 (Table 9 ), but no significant differences were observed in the apparent recovery of lignans.

\section{Variation Between Animals}

As shown in Figure 1, substantial variability was observed among cows on the same diet in milk equol concentration. The concentration of equol for cows on red clover diets in experiment 1 ranged from 500 to $2,200 \mu \mathrm{g} / \mathrm{kg}$ for cows on R2 and from 500 to $2,600 \mu \mathrm{g} /$ $\mathrm{kg}$ for cows on R3. In experiment 2, the range was generally lower than in experiment 1 (400 to $1,700 \mu \mathrm{g} / \mathrm{kg}$ for cows on S3).

\section{DISCUSSION}

\section{Effects of Regrowth Interval}

The concentrations of phytoestrogens were only slightly higher in silage mixture R3 than in R2. The slightly higher red clover proportion in silage mixture R2 might have diminished any differences in isoflavone concentrations associated with the difference in regrowth interval. Higher formononetin concentrations have been observed previously in red clover harvested with shorter regrowth intervals (6 vs. 8 wk of summer regrowth; Mustonen et al., 2009) and red clover of lesser maturity (Sarelli et al., 2003; Sivesind and Seguin, 2005; Booth et al., 2006). The regrowth interval did not have a large influence on silage secoisolariciresinol and matairesinol concentrations. However, the apparent recovery of lignans was almost twice as high for cows on R2 as for those on R3, indicating that the length of regrowth affected the metabolism of the ingested lignans.

\section{Effects of Botanical Composition}

Long-term leys in organically managed farms typically contain large proportions of unsown grasses and dicotyledons compared with short-term leys (Leiber et al., 2005); however, in L3 the proportion of unsown species was unexpectedly low. In the present experiment, the effects on phytoestrogen concentrations seemed mainly associated with the botanical composition of the silage more than the management or duration of the leys.

Formononetin, Daidzein, and Equol Contents. The most abundant phytoestrogen in all silage mixtures
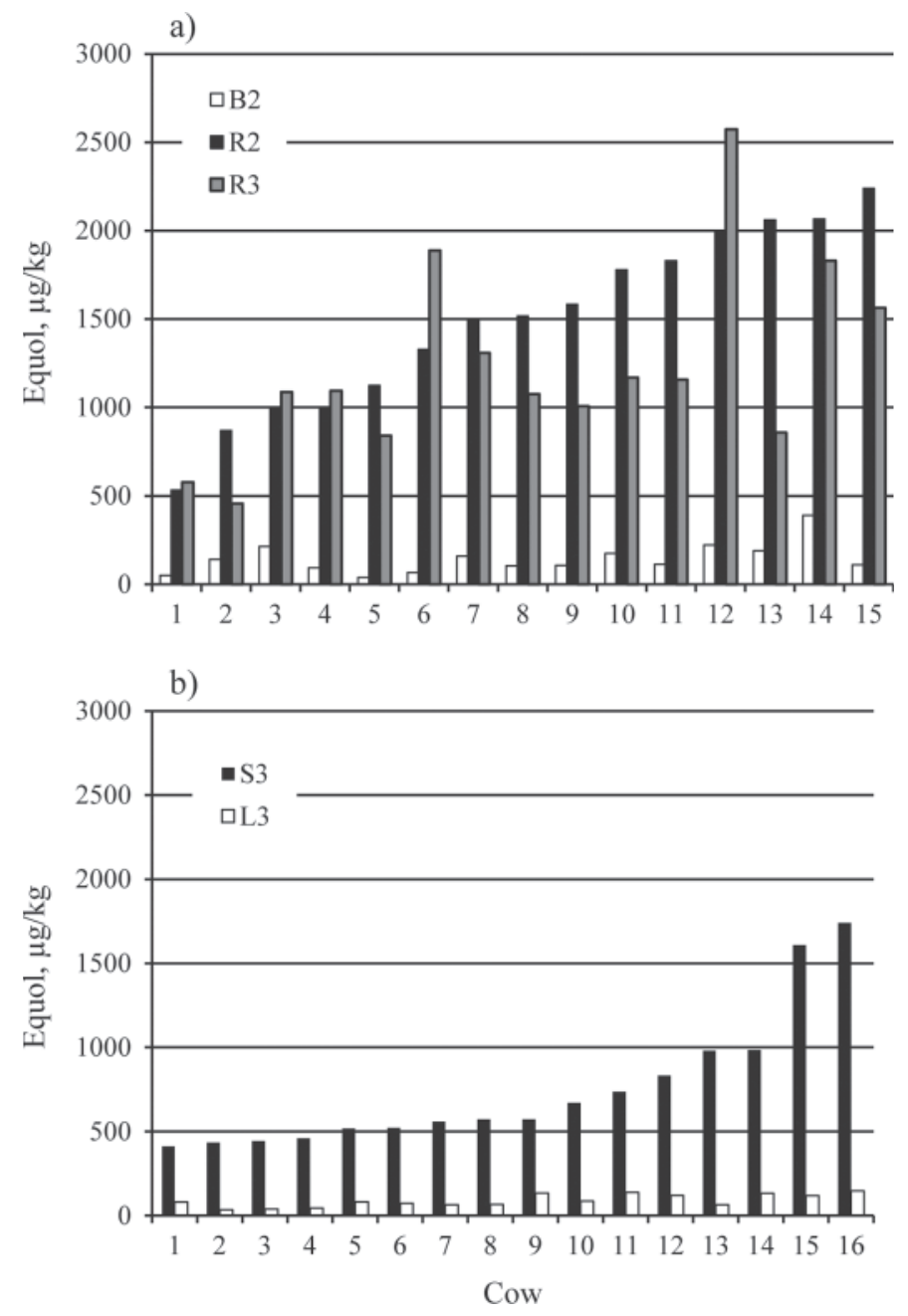

Figure 1. Variation in equol concentration $(\mu \mathrm{g} / \mathrm{kg})$ in milk among cows fed: (a) 2-cut birdsfoot trefoil-grass silage (B2), 2-cut red clovergrass silage (R2), or 3-cut red clover-grass silage (R3), and (b) shortterm ley silage (S3) or long-term ley silage (L3).

in the 2 experiments was formononetin; the concentration of daidzein was lower. Mixtures with red clover had the highest concentration of both formononetin and daidzein, which has also been shown in other studies (e.g., Sarelli et al., 2003; Andersen et al., 2009a; Mustonen et al., 2009). The concentrations of formononetin and daidzein in silage mixtures R2, R3, and S3 were lower than those in pure red clover silage, as reported by Mustonen et al. (2009) and by Sarelli et al. (2003), but much higher than those in silage with low proportions of red and white clover and a high proportion of grass, as reported by Andersen et al. (2009b).

Compared with silage mixtures R2 and R3, the concentrations of formononetin and daidzein were low in $\mathrm{B} 2$, indicating lower concentrations of isoflavones in birdsfoot trefoil compared with red clover. However, despite the low proportion of birdsfoot trefoil in silage 
mixture B2, the concentrations of formononetin and daidzein were higher than those in pure wilted birdsfoot trefoil reported by Sarelli et al. (2003). In experiment 2 , the silage mixture with white clover, L3, had lower concentrations of formononetin and daidzein than did red clover, including silage mixture S3, indicating that white clover, like birdsfoot trefoil, contains less isoflavones than does red clover. Formononetin concentration in silage mixture L3 was similar to the concentration in white clover-grass silage reported by Steinshamn et al. (2008) but was lower than that reported in fresh white clover-grass mixtures (Andersen et al., 2009a).

Milk equol concentrations on R2 and R3 were substantially higher than those reported previously. For example, in studies of Australian tank milk and Finnish commercial milk, the highest measured equol concentrations were 293 and $411 \mu \mathrm{g} / \mathrm{kg}$ of milk, respectively (King et al., 1998; Hoikkala et al., 2007). Further, the milk equol concentration was approximately 4 times higher for cows on R2 than the highest concentrations (364 $\mu \mathrm{g} / \mathrm{kg})$ recorded by Steinshamn et al. (2008) after feeding cows silage with a very similar proportion of red clover (0.41 vs. 0.39 ). It was also substantially higher than the milk equol concentrations recorded by Mustonen et al. (2009) after feeding cows red clover silage (410 to $695 \mu \mathrm{g} / \mathrm{kg}$ ) and by Andersen et al. (2009a) when cows were grazing a sward with a red clover proportion of $0.68(355 \mu \mathrm{g} / \mathrm{kg})$. The equol concentration for cows on B2 was much lower than for those on the red clover diets R2 and R3. Compared with experiment 2 , the equol concentration was higher than for cows on the white clover-grass silage diet L3. In experiment 2, the milk equol concentration was almost twice as high for cows on S3 as the highest concentration reported by Steinshamn et al. (2008). Milk concentrations of formononetin, daidzein, and equol for cows on L3 were comparable with reported concentrations for cows on white clover-grass silage in the study by Steinshamn et al. (2008), but were much higher than those reported for cows grazing white clover-grass swards (Andersen et al., 2009a).

When comparing experiments 1 and 2, a large difference was observed in milk concentrations of equol between diets R3 and S3; R3 had approximately 2-fold higher concentrations than did S3, despite similar or slightly higher formononetin and daidzein intakes. However, the high milk equol concentrations for cows on R2 and R3 cannot be explained solely by intake because the intake of formononetin was not higher than reported previously.

Both formononetin and daidzein are precursors of equol (Batterham et al., 1965). In some species (including humans, monkeys, chimpanzees, and rats), formononetin and daidzein can be metabolized into $O$ - desmethylangolensin, in addition to equol, as reviewed by Atkinson et al. (2005), but this metabolite has not been detected in bovine milk (Hoikkala et al., 2007; Mustonen et al., 2009). Equol is of interest because of its strong binding affinity, especially to estrogen receptor $\beta$ (Muthyala et al., 2004), and the consequential health effects. In humans, approximately $30 \%$ of all individuals carry gut bacteria that metabolize formononetin and daidzein to equol, and large interindividual variability exists in the efficiency of the metabolism (Rowland et al., 2000). All cattle are believed to be able to produce equol from ingested precursors (Atkinson et al., 2005), but as in humans, their rumen and intestinal microflora and the efficiency of the metabolism may vary. To assess these possibilities, we investigated the concentration of equol in milk produced by each individual cow on each treatment in the 2 experiments. Substantial variability was observed among cows on the same diet in this respect. The concentration of equol for cows on red clover diets in experiment 1 ranged from 500 to $2,200 \mu \mathrm{g} / \mathrm{kg}$ for cows on R2 and from 500 to $2,600 \mu \mathrm{g} / \mathrm{kg}$ for cows on R3. In experiment 2 , the range was generally lower than in experiment 1 (400 to $1,700 \mu \mathrm{g} / \mathrm{kg}$ for cows on S3). Differences in the rumen microflora and the passage rate of digesta between herds or between breeds may be responsible for these variations, but the biological reasons for these differences require further study. The interindividual variation in milk equol concentration opens the possibility of increasing or decreasing the effect of phytoestrogens on the animals, or influencing the concentration in milk.

The apparent recoveries of formononetin and daidzein were higher for cows on diets with lower intake of these substances (B2 and L3) than for those on diets with red clover (R2, R3, and S3). An inverse relationship between recovery and lower intake was also observed by Steinshamn et al. (2008), but Andersen et al. (2009b) found recoveries of formononetin and daidzein to be highest on the diet providing the highest intake of these substances. The discrepancies between R2 and B2 may be partly due to the presence of condensed tannins in birdsfoot trefoil (Hedqvist et al., 2000), which might affect rumen metabolism by inhibiting rumen microorganisms (Patra and Saxena, 2011) and thus increase the apparent recovery. The recovery was higher for S3 than was reported for a red clover-grass diet (Steinshamn et al. (2008; 0.48 vs. $0.24 \mathrm{mg} / \mathrm{g}$, respectively) but was lower than that reported by Andersen et al. (2009b; $1.23 \mathrm{mg} / \mathrm{g}$ ). Recovery for cows on L3 was comparable with results for those on white clover-grass silage (Steinshamn et al., 2008).

Biochanin $A$ and Genistein Contents. The phytoestrogen present in the second highest concentration in all silage mixtures was biochanin A. As seen 
for formononetin and daidzein, the concentrations of both biochanin A and genistein were highest in silage mixtures including red clover (R2, R3, and S3). Concentrations of biochanin $\mathrm{A}$ in all silage mixtures except L3 were higher than those in the grass-clover silage mixture (red and white clover), as reported by Andersen et al. (2009b), but in all mixtures they were lower than those in pure red clover silage, as reported by Mustonen et al. (2009) and Sarelli et al. (2003).

Because of the higher intakes of biochanin A and genistein for cows on R2, R3, and S3 than for those on B2 and L3, their milk concentrations were increased. The concentrations of biochanin A in milk were comparable for cows on R2, R3 and S3, but the concentration of genistein for cows on R2 and R3 was approximately 2-fold higher than for cows on S3. Compared with the highest concentration reported by Steinshamn et al. (2008), the milk concentration of genistein was 3 times higher for R2 and R3, and the concentration of biochanin A was almost twice as high for R2, R3, and S3. The concentrations on R2, R3, and S3 were also higher than those reported by Andersen et al. (2009b), but these authors used silage with lower proportions of clover (both red and white); thus, the intake was lower than in the present study. The concentrations of biochanin $\mathrm{A}$ on all diets in the present 2 experiments were higher than those reported from cows grazing swards with mixtures of grass together with red clover, white clover, alfalfa, or chicory (Cichorium intybus L.; Andersen et al., 2009a). The higher biochanin A and genistein concentrations on S3 than on L3 are in accordance with the results of Steinshamn et al. (2008), who found higher milk concentrations of these isoflavones on red clover-grass silage than on white clover-grass silage.

However, the apparent recoveries for biochanin A and genistein were low for cows on all diets compared with the other recoveries calculated in this paper. This is likely due to extensive degradation of biochanin A and genistein to $p$-ethylphenol, a metabolite lacking estrogenic activity (Batterham et al., 1965) and thus not analyzed in these experiments. Apparent recovery was many times higher for cows on B2 and L3 than for those on R2, R3, and S3. Compared with other studies, the apparent recoveries for cows on R2, R3, and S3 were higher than those reported for cows on red clover diets (Steinshamn et al., 2008) but were lower than those reported for cows on red and white clover-grass silages (Andersen et al., 2009b). Recoveries for cows on B2 and L3 were lower than the recovery for cows on alfalfa silage but were higher than the recovery for cows on grass-clover silage reported by Andersen et al. (2009b).

Prunetin Contents. As for the other isoflavones, the prunetin concentration was higher in silages mix- tures with a high proportion of red clover. The levels for R2, R3, and S3 were comparable with the concentration reported in red clover-grass silage (0.39 red clover) by Steinshamn et al. (2008), but were much higher than that reported in clover-grass silage (0.03 red and white clover) by Andersen et al. (2009b).

Intake of prunetin in the different treatments reflected the concentration in the silage mixtures, with lower intakes for B2 and L3 than for the diets containing red clover. However, the recovery was higher for the nonred-clover diets, resulting in much smaller differences in the milk compared with the differences in the silage mixtures. Low concentrations of prunetin have been reported previously in milk from cows on red clover-grass and white clover-grass silage (Steinshamn et al., 2008) and on alfalfa-corn silage (Andersen et al., 2009b) diets. The relatively low recoveries, especially on red clover diets, indicate that a large proportion of the ingested prunetin is either not absorbed or is highly degraded in the intestines and not transferred in its original form to the milk. We have not found any other published studies that have reported the recovery of prunetin.

Coumestrol Contents. The concentration of coumestrol in the silage mixtures was low in both experiments but was lowest in experiment 1 . All the studied species seemed to contain much lower coumestrol than has been reported for alfalfa. The concentration in silage mixture L3 was 10-fold lower and in silage mixture S3, it was 200 times lower than concentrations observed in alfalfa silage by Andersen et al. (2009b), and the concentrations in milk were also lower than those reported on alfalfa silage. The concentrations in milk in experiment 1 were just above the detection limit for all 3 diets, but in experiment 2, the concentrations were slightly higher. In other studies in which cows were fed diets with a composition comparable with those used in the present studies, the coumestrol concentration in milk has been below the detection limit (Antignac et al., 2004; Steinshamn et al., 2008).

Lignan Contents. Lignans are composed of dimerized hydroxycinnamic acids, substances that, when polymerized, generate lignin, a fibrous constituent of plants, as reviewed by Peterson et al. (2010). Thus, because lignin concentrations have been reported to increase in forage (at least in timothy) with maturity (Nordheim-Viken et al., 2009), silage lignan concentrations may do so too. However, in the experiments reported here, concentrations of secoisolariciresinol and matairesinol were similar or slightly higher in mixture R3 than in R2; hence, varying the regrowth interval had only a minor effect on lignan concentration in the silage mixture. On the other hand, the botanical composition seems to have had a large effect on lignan concentration in the silages and especially in the milk; 
lignan concentrations were higher in silage mixtures with other legumes than in red clover and in mixtures with higher grass proportions (B2 and L3), and in the milk, the differences were even larger than in the silage. Whether these differences were also a product of the botanical composition was not shown in the results from these 2 experiments.

The concentrations of enterolactone in milk for cows on L3 and B2 were much higher and the enterodiol concentration was much lower than were reported for cows grazing white clover swards (Andersen et al., 2009a) and cows fed white clover-grass silage (Steinshamn et al., 2008). Despite lower intakes of secoisolariciresinol on all diets than for cows on flaxseed in a study by Petit et al. (2009), the concentration of enterolactone in milk was much higher for cows on all diets in the present study. Enterolactone is the end product of secoisolariciresinol and matairesinol metabolism (Peterson et al., 2010). However, when matairesinol is metabolized directly to enterolactone, secoisolariciresinol is first degraded to enterodiol and then to enterolactone. In the present study, a large proportion of the produced enterodiol may have been further oxidized to enterolactone, thus explaining the high enterolactone concentrations. In addition, the high matairesinol concentration in the silage mixtures (especially in silage mixture B2) may have further increased the enterolactone concentrations. No lignans were detected in the concentrates, although barley (one of the constituents) is known to have other lignans than those analyzed in the present experiment (Smeds et al., 2007; Peterson et al., 2010). Some of these unanalyzed lignans may also be converted into the mammalian lignans enterodiol and enterolactone (Heinonen et al., 2001) and may partly explain the high enterolactone concentration.

The higher milk concentrations of the mammalian lignans enterodiol and enterolactone for cows on L3 than for those on S3 and for cows on B2 than for those on R2 and R3 are probably due to a higher intake because no significant differences were observed in the apparent recovery of lignans between these diets. Other mechanisms might also be affecting lignan metabolism in the rumen and intestines.

\section{Intake of Phytoestrogens in Humans}

The intake of whole milk is reported to be 351 and $255 \mathrm{~g} / \mathrm{d}$ in the United States and Europe, respectively (FAOSTAT, 2010). If milk from cows fed R2 were consumed, it would give an intake of 520 or $380 \mu \mathrm{g}$ of equol/d for the US or European population, respectively. If milk from cows fed L3 were consumed instead, the intake of equol would be approximately $25 \mu \mathrm{g}$ of equol/d. As a comparison, studies have reported a total phytoestrogen intake of between 1,200 and $1,800 \mu \mathrm{g} / \mathrm{d}$ (Cotterchio et al., 2008; Ward et al., 2010), 1,000 $\mu \mathrm{g} / \mathrm{d}$ of only isoflavones (Chun et al., 2009), and $360 \mu \mathrm{g} / \mathrm{d}$ of daidzein (Frankenfeld, 2011). However, for many consumers, the intake of phytoestrogens is much lower than the cited average intake (Ward and Kuhnle, 2010; Frankenfeld, 2011). As milk and milk products are consumed by a large part of the population, increasing the phytoestrogen concentration in the milk might have widespread health effects.

\section{CONCLUSIONS}

Legumes in forage mixtures are valuable for their $\mathrm{N}$ fixation. This study showed the possibilities of choosing the level and composition of phytoestrogens in milk by choosing the legume species and proportion of legumes in the forage. White clover or birdsfoot trefoil, as legumes in the sward, decreased the isoflavonoid concentrations in milk compared with red clover-grass silages, but lignan concentrations in the silage and milk increased. When feeding red clover-grass silage, the intake of isoflavones (mainly formononetin and biochanin A) was high and the milk equol concentrations were increased. However, variations in equol concentration between individual cows were large in this study, indicating the possibility of selecting high or low producers of equol. The regrowth interval affected the apparent recovery of lignans but did not affect milk lignan or isoflavonoid concentrations. If the milk from these experiments were consumed, the intake of phytoestrogens, especially equol, would be increased for a large part of the population. In future studies, it will be important to analyze more mammalian lignan precursors, especially in silage, and the phytoestrogen concentrations in separate forage species. Knowledge of the metabolism of some phytoestrogens needs to be enhanced, and it is important to further explore the interindividual variation among cows in the efficiency of metabolizing formononetin and daidzein to equol.

\section{ACKNOWLEDGMENTS}

The authors acknowledge the financial support from the members of the CORE Organic Funding Body Network [being former partners of the FP6 ERA-net project CORE Organic (Tjele, Denmark)], the Swedish Research Council Formas (Stockholm, Sweden), the Research Council of Norway (Oslo, Norway), and the Danish Research Council (Copenhagan, Denmark). The authors thank Lis Sidelmann (Department of Animal Science, Aarhus University, Tjele, Denmark) for technical assistance in analyzing concentrations of 
phytoestrogens in the silage and milk. We also thank the staff at the two research barns and the laboratories.

\section{REFERENCES}

Andersen, C., T. S. Nielsen, S. Purup, T. Kristensen, J. Eriksen, K. Søegaard, J. Sørensen, and X. C. Fretté. 2009a. Phyto-oestrogens in herbage and milk from cows grazing white clover, red clover, lucerne or chicory-rich pastures. Animal 3:1189-1195. http:// dx.doi.org/10.1017/S1751731109004613.

Andersen, C., M. R. Weisbjerg, J. Hansen-Møller, and K. Sejrsen. $2009 \mathrm{~b}$. Effect of forage on the content of phyto-oestrogens in bovine milk. Animal 3:617-622. http://dx.doi.org/10.1017/ S1751731108003698.

Antignac, J. P., R. Cariou, B. Le Bizec, and F. André. 2004. New data regarding phytoestrogens content in bovine milk. Food Chem. 87:275-281. http://dx.doi.org/10.1016/j.foodchem.2003.12.013.

AOAC. 1990. Official Methods of Analysis. 15th ed. Assoc. Anal. Chem., Arlington, VA.

Atkinson, C., C. L. Frankenfeld, and J. W. Lampe. 2005. Gut bacterial metabolism of the soy isoflavone daidzein: Exploring the relevance to human health. Exp. Biol. Med. 230:155-170.

Batterham, T. J., N. K. Hart, J. A. Lamberton, and A. W. H. Braden. 1965. Metabolism of oestrogenic isoflavones in sheep. Nature 206:509.

Booth, N. L., C. R. Overk, P. Yao, S. Totura, Y. Deng, A. S. Hedayat, J. L. Bolton, G. F. Pauli, and N. R. Farnsworth. 2006. Seasonal variation of red clover (Trifolium pratense L., Fabaceae) isoflavones and estrogenic activity. J. Agric. Food Chem. 54:12771282. http://dx.doi.org/10.1021/jf052927u.

Chun, O. K., S. J. Chung, and W. O. Song. 2009. Urinary isoflavones and their metabolites validate the dietary isoflavone intakes in US adults. J. Am. Diet. Assoc. 109:245-254. http://dx.doi. org/10.1016/j.jada.2008.10.055.

Cotterchio, M., B. A. Boucher, N. Kreiger, C. A. Mills, and L. U. Thompson. 2008. Dietary phytoestrogen intake - lignans and isoflavones - and breast cancer risk (Canada). Cancer Causes Control 19:259-272. http://dx.doi.org/10.1007/s10552-007-9089-2.

FAOSTAT. 2010. Food Supply-Livestock and Fish Primary Equivalent. FAOSTAT, Rome, Italy.

Frankenfeld, C. L. 2011. Dairy consumption is a significant correlate of urinary equol concentration in a representative sample of US adults. Am. J. Clin. Nutr. 93:1109-1116. http://dx.doi. org/10.3945/ajcn.111.011825.

Gustavsson, A.-M. 2011. A developmental scale for perennial forage grasses based on the decimal code framework. Grass Forage Sci. 66:93-108.

Hall, M. B., W. H. Hoover, J. P. Jennings, and T. K. Miller Webster. 1999. A method for partitioning neutral detergent-soluble carbohydrates. J. Sci. Food Agric. 79:2079-2086.

Hedqvist, H., I. Mueller-Harvey, J. D. Reed, C. G. Krueger, and M. Murphy. 2000. Characterisation of tannins and in vitro protein digestibility of several Lotus corniculatus varieties. Anim. Feed Sci. Technol. 87:41-56. http://dx.doi.org/10.1016/s03778401(00)00178-4.

Heinonen, S., T. Nurmi, K. Liukkonen, K. Poutanen, K. Wähälä, T. Deyama, S. Nishibe, and H. Adlercreutz. 2001. In vitro metabolism of plant lignans: New precursors of mammalian lignans enterolactone and enterodiol. J. Agric. Food Chem. 49:3178-3186. http://dx.doi.org/10.1021/jf010038a.

Hoikkala, A., E. Mustonen, I. Saastamoinen, T. Jokela, J. Taponen, H. Saloniemi, and K. Wähälä. 2007. High levels of equol in organic skimmed Finnish cow milk. Mol. Nutr. Food Res. 51:782-786. http://dx.doi.org/10.1002/mnfr.200600222.

Huhtanen, P., K. Kaustell, and S. Jaakkola. 1994. The use of internal markers to predict total digestibility and duodenal flow of nutrients in cattle given six different diets. Anim. Feed Sci. Technol. 48:211-227. http://dx.doi.org/10.1016/0377-8401(94)90173-2.
Ingram, D., K. Sanders, M. Kolybaba, and D. Lopez. 1997. Casecontrol study of phyto-oestrogens and breast cancer. Lancet 350:990-994.

King, R. A., M. M. Mano, and R. J. Head. 1998. Assessment of isoflavonoid concentrations in Australian bovine milk samples. J. Dairy Res. 65:479-489.

Kuhnle, G. G. C., C. Dell'Aquila, S. M. Aspinall, S. A. Runswick, A. A. Mulligan, and S. A. Bingham. 2008. Phytoestrogen content of foods of animal origin: Dairy products, eggs, meat, fish, and seafood. J. Agric. Food Chem. 56:10099-10104. http://dx.doi. org/10.1021/jf801344x.

Leiber, F., M. Kreuzer, D. Nigg, H. R. Wettstein, and M. R. L. Scheeder. 2005. A study on the causes for the elevated n-3 fatty acids in cows' milk of alpine origin. Lipids 40:191-202.

Lund, T. D., C. Blake, L. H. Bu, A. N. Hamaker, and E. D. Lephart. 2011. Equol an isoflavonoid: Potential for improved prostate health, in vitro and in vivo evidence. Reprod. Biol. Endocrinol. 9:9. http://dx.doi.org/10.1186/1477-7827-9-4.

Lundh, T. J. O., H. I. Pettersson, and K. A. Martinsson. 1990. Comparative levels of free and conjugated plant estrogens in bloodplasma of sheep and cattle fed estrogenic silage. J. Agric. Food Chem. 38:1530-1534.

Mazur, W., and H. Adlercreutz. 1998. Naturally occurring oestrogens in food. Pure Appl. Chem. 70:1759-1776.

Moravcová, J., T. Kleinová, R. Loucka, I. Tyrolová, F. Kvasnicka, M. Dusek, M. Cerovský, and P. Matucha. 2004. Coumestrol content of alfalfa following ensilage. Anim. Feed Sci. Technol. 115:159-167.

Mustonen, E. A., M. Tuori, I. Saastamoinen, J. Taponen, K. Wähälä, H. Saloniemi, and A. Vanhatalo. 2009. Equol in milk of dairy cows is derived from forage legumes such as red clover. Br. J. Nutr. 102:1552-1556.

Muthyala, R. S., Y. H. Ju, S. B. Sheng, L. D. Williams, D. R. Doerge, B. S. Katzenellenbogen, W. G. Helferich, and J. A. Katzenellenbogen. 2004. Equol, a natural estrogenic metabolite from soy isoflavones: Convenient preparation and resolution of $R$ - and $S$-equols and their differing binding and biological activity through estrogen receptors alpha and beta. Bioorg. Med. Chem. 12:1559-1567. http://dx.doi.org/10.1016/j.bmc.2003.11.035.

Nordheim-Viken, H., H. Volden, and M. Jørgensen. 2009. Effects of maturity stage, temperature and photoperiod on growth and nutritive value of timothy (Phleum pratense L.). Anim. Feed Sci. Technol. 152:204-218. http://dx.doi.org/10.1016/j.anifeedsci.2009.04.012.

NRC. 2001. Nutrient Requirements of Dairy Cattle. 7th ed. Natl. Acad. Press, Washington, DC.

Ososki, A. L., and E. J. Kennelly. 2003. Phytoestrogens: A review of the present state of research. Phytother. Res. 17:845-869. http:// dx.doi.org/10.1002/ptr.1364.

Patra, A. K., and J. Saxena. 2011. Exploitation of dietary tannins to improve rumen metabolism and ruminant nutrition. J. Sci. Food Agric. 91:24-37. http://dx.doi.org/10.1002/jsfa.4152.

Patterson, H. D., and H. L. Lucas. 1962. Change-over designs. North Carolina Agric. Exp. Sta. Tech. Bull. 147:1-52.

Peterson, J., J. Dwyer, H. Adlercreutz, A. Scalbert, P. Jacques, and M. L. McCullough. 2010. Dietary lignans: Physiology and potential for cardiovascular disease risk reduction. Nutr. Rev. 68:571-603. http://dx.doi.org/10.1111/j.1753-4887.2010.00319.x.

Petit, H. V., N. Gagnon, P. S. Mir, R. Cao, and S. Cui. 2009. Milk concentration of the mammalian lignan enterolactone, milk production, milk fatty acid profile, and digestibility in dairy cows fed diets containing whole flaxseed or flaxseed meal. J. Dairy Res. 76:257-264. http://dx.doi.org/10.1017/s0022029909003999.

Rowland, I. R., H. Wiseman, T. A. B. Sanders, H. Adlercreutz, and E. A. Bowey. 2000. Interindividual variation in metabolism of soy isoflavones and lignans: Influence of habitual diet on equol production by the gut microflora. Nutr. Cancer 36:27-32.

Sarelli, L., M. Tuori, I. Saastamoinen, L. Syrjala-Qvist, and H. Saloniemi. 2003. Phytoestrogen content of birdsfoot trefoil and red clover: Effects of growth stage and ensiling method. Acta Agric. Scand. Anim. Sci. 53:58-63. http://dx.doi. org/10.1080/09064700310002053. 
SAS Institute. 2008. SAS/STAT Software. Release 9.2. SAS Inst. Inc., Cary, NC.

Saviranta, N. M. M., M. J. Anttonen, A. von Wright, and R. O. Karjalainen. 2008. Red clover (Trifolium pratense L.) isoflavones: Determination of concentrations by plant stage, flower colour, plant part and cultivar. J. Sci. Food Agric. 88:125-132. http://dx.doi. org $/ 10.1002 /$ jsfa.3056.

Seguin, P., W. Zheng, and A. Souleimanov. 2004. Alfalfa phytoestrogen content: Impact of plant maturity and herbage components. J. Agron. Crop Sci. 190:211-217.

Sivesind, E., and P. Seguin. 2005. Effects of the environment, cultivar, maturity, and preservation method on red clover isoflavone concentration. J. Agric. Food Chem. 53:6397-6402. http://dx.doi. org $/ 10.1021 /$ jf0507487

Sjaunja, L. O., L. Baevre, L. Junkkarinen, J. Pedersen, and J. Setala. 1991. A Nordic proposal for an energy corrected milk (ECM) formula. Pages 156-192 in Performance Recording of Animals: State of the Art, 1990. Eur. Assoc. Anim. Prod. Publ. No. 50. 27th Biennial Session of the Int. Comm. Anim. Recording, Paris, France. Centre for Agricultural Publishing and Documentation, Wageningen, the Netherlands.

Smeds, A. I., P. C. Eklund, R. E. Sjöholm, S. M. Willför, S. Nishibe, T. Deyama, and B. R. Holmbom. 2007. Quantification of a broad spectrum of lignans in cereals, oilseeds, and nuts. J. Agric. Food Chem. 55:1337-1346. http://dx.doi.org/10.1021/jf0629134.

Steinshamn, H., S. Purup, E. Thuen, and J. Hansen-Møller. 2008. Effects of clover-grass silages and concentrate supplementation on the content of phytoestrogens in dairy cow milk. J. Dairy Sci. 91:2715-2725. http://dx.doi.org/10.3168/jds.2007-0857.
Tousen, Y., J. Ezaki, Y. Fujii, T. Ueno, M. Nishimuta, and Y. Ishimi. 2011. Natural $S$-equol decreases bone resorption in postmenopausal, non-equol-producing Japanese women: A pilot randomized, placebo-controlled trial. Menopause-J. N. Am. Menopause Soc. 18:563-574. http://dx.doi.org/10.1097/gme.0b013e3181f85aa7.

Tucker, H. A., K. F. Knowlton, M. T. Meyer, W. O. Khunjar, and N. G. Love. 2010. Effect of diet on fecal and urinary estrogenic activity. J. Dairy Sci. 93:2088-2094. http://dx.doi.org/10.3168/ jds.2009-2657.

Volden, H. 2011. NorFor-The Nordic Feed Evaluation System. Vol. 130. Eur. Assoc. Anim. Prod. Publ. Wageningen Academic Publishers, Wageningen, the Netherlands.

Ward, H. A., and G. G. C. Kuhnle. 2010. Phytoestrogen consumption and association with breast, prostate and colorectal cancer in EPIC Norfolk. Arch. Biochem. Biophys. 501:170-175. http:// dx.doi.org/10.1016/j.abb.2010.05.018.

Ward, H. A., G. G. C. Kuhnle, A. A. Mulligan, M. A. H. Lentjes, R. N. Luben, and K. T. Khaw. 2010. Breast, colorectal, and prostate cancer risk in the European Prospective Investigation into Cancer and Nutrition-Norfolk in relation to phytoestrogen intake derived from an improved database. Am. J. Clin. Nutr. 91:440-448. http://dx.doi.org/10.3945/ajcn.2009.28282.

Zgórka, G. 2009. Ultrasound-assisted solid-phase extraction coupled with photodiode-array and fluorescence detection for chemotaxonomy of isoflavone phytoestrogens in Trifolium L. (Clover) species. J. Sep. Sci. 32:965-972. http://dx.doi.org/10.1002/jssc.200800456. 